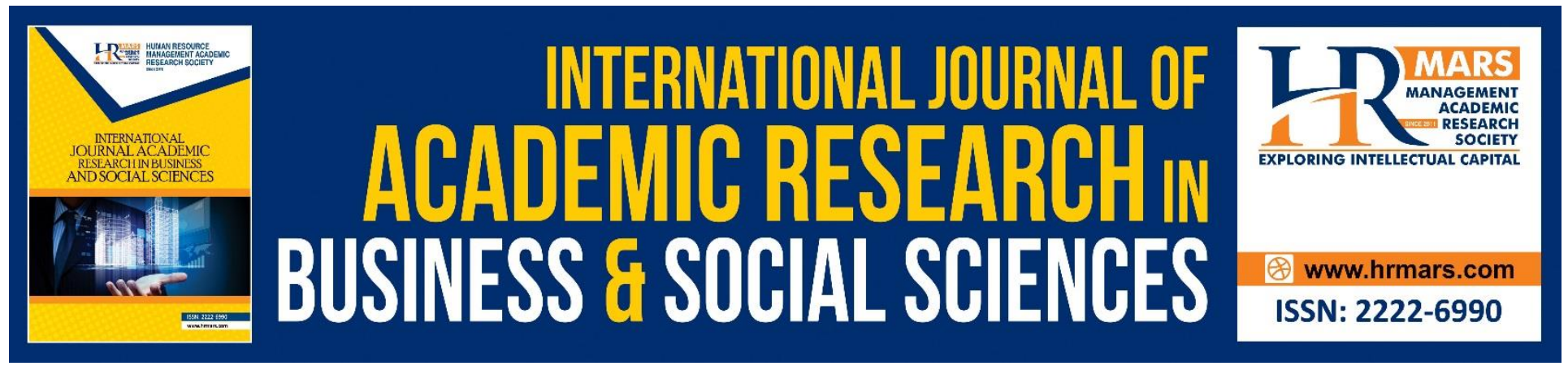

\title{
Sustainable Development: Needs of Green Skills in the Fourth Industrial Revolution (4IR)
}

Syarina Ramli, Mohamad Sattar Rasul, Haryanti Mohd Affandi

To Link this Article: http://dx.doi.org/10.6007/IJARBSS/v8-i9/4682

DOI: $\quad 10.6007 /$ IJARBSS/v8-i9/4682

Received: 09 August 2018, Revised: 28 August 2018, Accepted: 16 Sept 2018

Published Online: 29 October 2018

In-Text Citation: (Ramli, Rasul, \& Affandi, 2018)

To Cite this Article: Ramli, S., Rasul, M. S., \& Affandi, H. M. (2018). Sustainable Development: Needs of Green Skills in the Fourth Industrial Revolution (4IR). International Journal of Academic Research in Business and Social Sciences, 8(9), 1082-1095.

Copyright: (C) 2018 The Author(s)

Published by Human Resource Management Academic Research Society (www.hrmars.com)

This article is published under the Creative Commons Attribution (CC BY 4.0) license. Anyone may reproduce, distribute, translate and create derivative works of this article (for both commercial and non-commercial purposes), subject to full attribution to the original publication and authors. The full terms of this license may be seen

at: http://creativecommons.org/licences/by/4.0/legalcode

Vol. 8, No. 9, September 2018, Pg. 1082 - 1095

http://hrmars.com/index.php/pages/detail/IJARBSS

JOURNAL HOMEPAGE

Full Terms \& Conditions of access and use can be found at http://hrmars.com/index.php/pages/detail/publication-ethics 


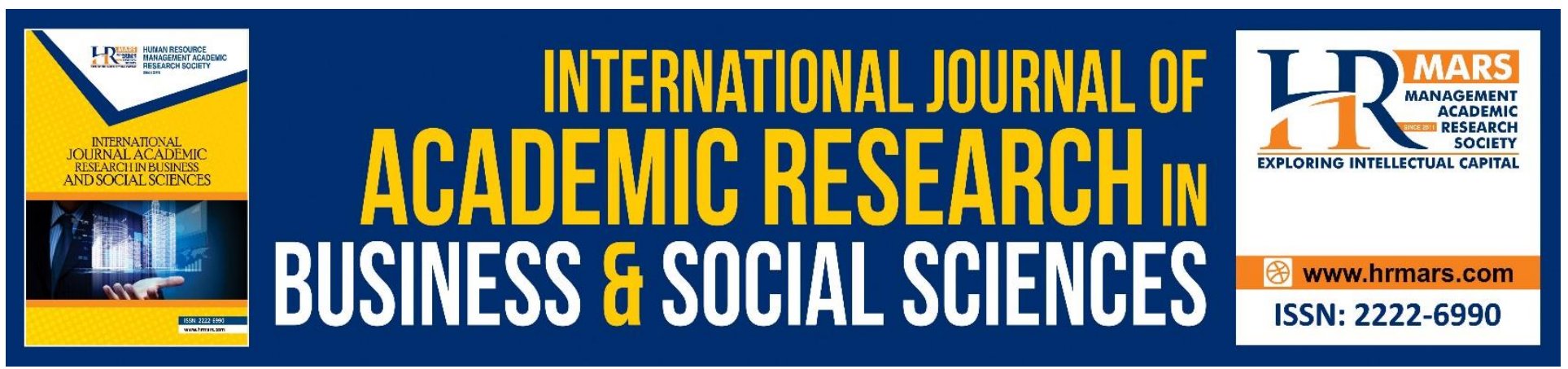

\title{
Sustainable Development: Needs of Green Skills in the Fourth Industrial Revolution (4IR)
}

\author{
Syarina Ramli, Mohamad Sattar Rasul, Haryanti Mohd Affandi \\ The National University of Malaysia \\ Corresponding Author Email: drsattar@ukm.edu.my
}

\begin{abstract}
Sustainable Development (SD) is the biggest challenge to the 21st century and transition to Fourth Industrial Revolution (4IR). Thus, green skills become a key of transforming into a low-carbon economy and innovation of Fourth Industrial Revolution (4IR). With 11 $1^{\text {th } M a l a y s i a ~ P l a n ~(2016-2020), ~}$ an economic development defined six strategic thrusts to help Malaysia achieve the target of becoming an advanced economy by year 2020 in a resilient, low carbon missions, resource efficient, and socially inclusive manner. Green skills are one of the strategic thrusts that will enable Malaysia to stay ahead of environmental challenges and opportunities in a fast-changing global and political landscape. Besides that, one of the agendas of ACET 2015 is to integrate green skills for the preservation of the TVET program to achieve sustainable development including curbing poverty and inclusive of economic development. This article will discuss the needs of green skills for sustainable development in Fourth Industrial Revolution (4IR). The needs are focusing on employee productivity, green technologies, and education and skills for green economy, social and environment. A review of various published documents has been used to provide a comprehensive literature of the need of green skills for sustainable development in 4IR. At the end, after several needs are identified, the technical and vocational education, through a greater sustainability-related curriculum, plays a crucial role in educating students to be aware of the environment and the integration of green skills in the TVET curriculum is a must. In addition, TVET is an agent that facilitates the creation of a sustainable workforce towards the Fourth Industry Revolution.
\end{abstract}

Keywords: Sustainable Development, Green Skills and Fourth Industrial Revolution

\section{Introduction}

Industrialization has led to many of the world's current environmental problems. For example, climate change, unsafe levels of air pollution, the depletion of fishing stocks, toxins in rivers and soils, overflowing levels with waste on land and in the ocean, loss of biodiversity and deforestation can all be traced to industrialization (World Economic Forum, 2017). As the Fourth Industrial Revolution gathers pace, innovations are becoming faster, more efficient and more widely accessible than 
before. Technology is also becoming increasingly connected; in particular, we are seeing a merging of digital, physical and biological realms. New technologies are enabling societal shifts by having an effect on economics, values, identities and possibilities for future generations. Hence, green skills are so important and needed for the 4IR to be a sustainable revolution.

The Green Skills Agreement (2010-2011) defines skills for sustainability also known as green skills, are the technical skills, knowledge, values and attitudes needed in the workforce to develop and support sustainable social, economic and environmental outcomes in business, industry and the community. According to (Cedefop, 2014) green skills define as skills needed in a low-carbon economy, will be required in all sectors and at all levels in the workforce as emerging economic activities create new (or renewed) occupations. Structural changes will realign sectors that are likely to decline as a result of the green of the economy and workers will need to be retrained accordingly. The successful transition to a low-carbon economy will only be possible if workers can flexibly adapt and transfer from areas of decreasing employment to new industries.

However, Vona, Marin, Consoli and Popp (2015) in their research found out that green skills is a set from the efficiency that is related to design, output, management and technology monitoring. In the research findings, they discovered that the rules of the environment sparked a change in technology and organization that increases the demand for a higher analytical and technical skill. Green skills are also known as sustainable development skills. It refers to skills, knowledge, and attitudes needed by labor to support and promote sustainable social and economic development and to improve environment development friendly in business and communities.

\section{Conceptual Framework}

The conceptual framework of this article is coherent and connected with the related literature of this article. Below is the diagram of the conceptual framework that will discuss in this article.

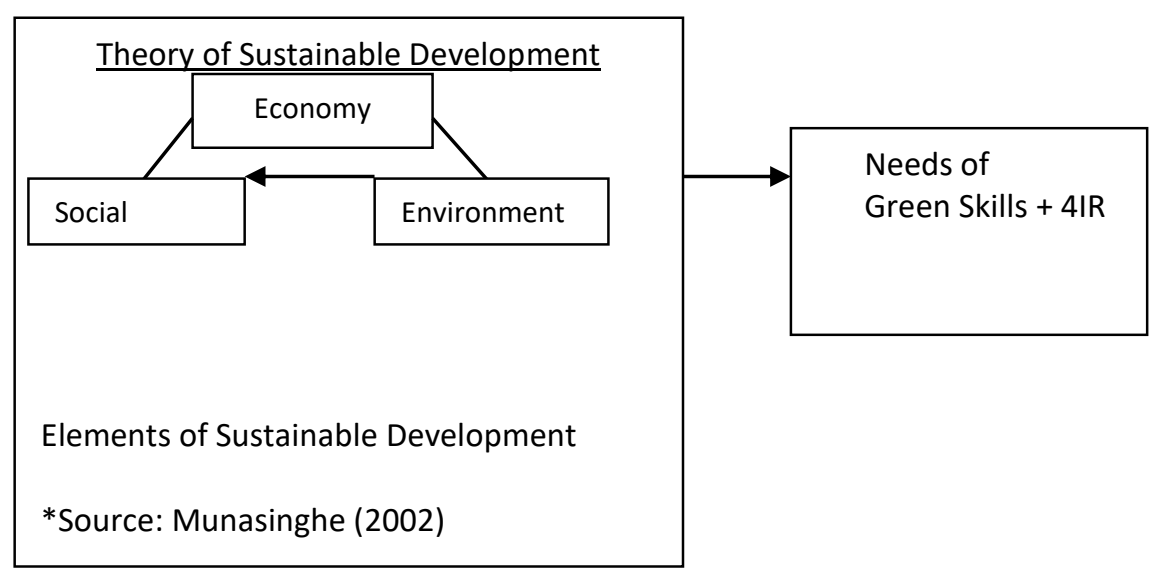

Sustainable development requires a balanced and integrated analysis from three main points of view: economic, social and environmental. Each viewpoint represents a domain and a system that 
INTERNATIONAL JOURNAL OF ACADEMIC RESEARCH IN BUSINESS AND SOCIAL SCIENCES Vol. 8, No. 9, Sept. 2018, E-ISSN: 2222-6990 (C) 2018 HRMARS

has its own distinct driving forces and objectives (Munasinghe, 2002, p.18). The objectives of three elements are:

i. Economic - maximizing income, while maintaining a constant or increasing stock of capital,

ii. Environment - maintaining resilience and robustness of biological and physical systems

iii. Social - maintaining stability of social and cultural systems

Based on the elements of economic, environment, and social, it will derive to the issues and needs in green skills development towards 4IR.

\section{Problem Statement}

Malaysia is a developing country and its population is projected to rise to 41.5 million by year 2040 (Statistic Department, 2016). Growing number of population means more energy consumption, more waste is produced, lack of resources and land mass, and decreasing from living quality. Thus, Tun Dr. Mahathir Mohamed (Malaysia's Prime Minister) has stated Malaysia's commitment to Sustainable Development by the year 2020 (Ikmal Rashmy, 2015)

Under vision 2020, we also need to prepare for the inevitable fourth industrial revolution (4IR), which is basically about digital economy, artificial intelligence (AI), the Internet of things (IoT), cross border e-commerce, and many more. Furthermore, as Malaysia strives towards becoming a developed nation by the year 2020 on prepare the nation and youth for the challenges of $4 I R$, there has been rapid increase in energy consumption which has resulted in depletion of primary non renewable energy resources and increase of greenhouse gases (GHGs) (Yatim, Ngan and Lam, 2017). Hence, the Malaysian government has launched a series of plans to encourage the utilization of renewable energy. These plan has instituted several policies include National Renewable Energy Policy and Action Plan (2009), National Policy on Climate Change (2009), National Green Technology Policy (2009) and Renewable Energy Act (2011). Malaysia is also a signatory to several multilateral environmental agreements (MEAs) such as ASEAN Agreement on Tramsboundary Haze, CPB, UNFCC, WHC and others.

Chinhao et al (2015) had stated in their study about the use energy in Malaysia, by year 2050 renewable energy will contribute $56 \%$ of electricity generation, whereas $43 \%$ will be contributed by large hydropower. However, the development of renewable energy has been much slower than expected. In addition, Malaysians still lack of energy conservation awareness because of the low energy prices. To address the challenge to global climate change, more emphasis must be placed on the utilization of renewable energy, green technology and energy conservation in Malaysia, and the energy subsidy for fossil fuel must be gradually reduced. Therefore, these drivers have an impact on the need of green skills as economies become more green (Strietska-Ilina, 2011) towards sustainable revolution in $4 I R$. 
Achieving low carbon world is manifest in three significant benefits: reduced emissions, higher productivity of the economy, and inclusive growth (Ramlee, 2015). However, climate change continues to be a major threat as it adversely impacts economic and social development gains and deepens economic inequalities. Over-exploitation of natural resources, unsustainable use of land, illegal deforestation, loss of biodiversity, and land-use change will weaken the provision of ecosystem services, increase vulnerability to climate-related disasters, and jeopardise the needs of present and future generations. In the Eleventh Plan, Malaysia is breaking free with the conventional wisdom of development at all costs to green growth, which is a more sustainable path of growth. This will see Malaysia enter the ranks of advanced economies in 2020 with an economy resilient to the adverse impact on climate change and with secure and sufficient supply of natural resources such as water, food, and energy. Partnership and shared responsibility for all levels of society, including individuals, will be key to safeguarding the environment and biodiversity. Successful green growth will not only expand economic opportunities, but also enhance inclusivity and reduce disaster risks (Chapter 6, $11^{\text {th }}$ Malaysia Plan). 11 ${ }^{\text {th }}$ Malaysia Plan 2016-2020, an economic development blueprint defined six strategic thrusts to help Malaysia achieve the target of becoming an advanced economy by year 2020 in a resilient, low carbon missions, resource efficient, and socially inclusive manner. Hence, green skills are one of the strategic thrusts that will enable Malaysia to stay ahead of environmental challenges and opportunities in a fast-changing global and political landscape. (KeTTHA, 2016)

The implementation of climate change commitments is leading to new skill requirements. While some areas require altogether new skills, a large number of existing occupations require additional skills and competencies in the context of efforts to move toward a low-carbon world. New types of skills and competencies will need to be incorporated into existing occupational profiles of the workforces. Asia Business Council (2009) predicts that the number of green jobs created by 2030 could reach 100 million worldwide, which is estimated at $2 \%$ of the future workforce. Roughly, Asia could have 50 million green jobs, and many jobs of the existing industries would require green skills as manufacturing sector may change their production processes using clean technology or they may develop green products (Maclean et al., 2013). Thus, there is needing for developing new "green" training curricula. Vocational and technical training will be critical in building the necessary skill base for green jobs. With that, (ACET, 2015) drafts eight main agendas that focus on the empowerment of the Educational with Technical and Vocational Exercise field as contained in the Kuala Lumpur Declaration as a preparation to fulfill job markets and capability to adapt self with the 21st century challenges. One of the 4 out of 8 agendas in the declaration is to integrate green skills for the preservation of the TVET program to achieve sustainable development including curbing poverty and inclusive of economic development. Since green skills have become one of the policy agenda in Malaysia's sustainable development, it is imperative to look at the needs of green skills development towards 4IR.

\section{Purpose of Study}

The major purpose of the study is to examine the challenges and improvement strategies of green skills for sustainable development in 4IR in Malaysia. Specifically, the study seeks to identify the needs of green skills for sustainable development in $4 \mathrm{IR}$ 


\section{Methodology}

This article use a systematic literature review using papers published from journals and conferences. A systematic literature review (SLR) is defined as a process of identifying, assessing, and interpreting all available research evidence with the purpose to provide answers for specific research questions (Kitchenham and Charters, 2007).

For searching electronic articles, various journal databases used, Google Advanced Scholar, ScienceDirect, UKM Journal Repository, Emerald, Research Gate, Weforum, and etc. This search is carried out using three keywords that the sustainable development, green skills and Fourth Industrial Revolution. By using document analysis, various documents have been used to obtain a general idea and perspective in this study.

Table 1 shows a summary of articles obtained by using keyword green skill. Researcher has to conducted search without using placing keywords limits to any field of study. Thus, a total of 113 articles successfully accessed to be referred.

\begin{tabular}{llc}
\hline No. & \multicolumn{1}{c}{ Key words } & Total \\
1. & Sustainable development & 80 \\
2. & Green Skills & 30 \\
3. & Fourth Industrial Revolution & 3 \\
\hline & Total & 113 \\
\hline
\end{tabular}

Table 1: Total articles from systematic review.

\section{Findings and Discussion}

\section{What are the needs of green skills towards 4IR?}

\section{Need 1: Increasing employee productivity}

In 2011, 12.2 million Malaysians were gainfully employed while the unemployment rate was 3.3 per cent. The number of new vacancies reported by occupation was about 1.3 million while the total jobseekers were only 0.3 million. Most hiring activities come from the manufacturing, agriculture and construction sectors. The mismatch between available jobs and expectations of people seeking work was partly explained by a government survey in 2008 which reported that graduates were unwilling to take on jobs deemed dirty, difficult or dangerous and many had "unrealistic" pay expectations. As most Malaysians are becoming highly educated, the government, in parallel, is aiming to generate more appropriate high skilled jobs, preferably green jobs, in growing and emerging sectors (ILO, 2014).

As the economists Erik Brynjolfsson and Andrew McAfee have pointed out in WEF (2016), the Fourth Industrial Revolution could yield greater inequality, particularly in its potential to disrupt labor markets. As automation substitutes for labor across the entire economy, the net displacement of workers by machines might exacerbate the gap between returns to capital and returns to labor. On the other hand, it is also possible that the displacement of workers by technology will, in aggregate, 
result in a net increase in safe and rewarding jobs. According to Caldecott et.al (2017), the example of the Limburg region in the Netherlands illustrated that higher levels of reemployment, company reinvestment in new business models, and regional economic regeneration are possible given time, reinvestment and sufficient social and political consensus. For instance, in that case, a transition of approximately 75,000 mining workers into alternative employment (or in some cases retirement) was achieved over a period of ten years. A significant percentage of affected workers were also able to be retrained and find new employment in the same coalmining company, as it diversified into other activities in the region, most notably chemicals. Unplanned transitions often led to multiple problems: higher rates of long-term unemployment and 'inactive' prime-age workers unable to reenter the labour force, higher risks of large companies going bankrupt, poorer long-term regional economic performance, lower tax revenues for local services, unpaid-for environmental remediation, and unpaid pension and/or health care programmes. For example, in the United Kingdom the lack of anticipation and active management of the removal of support for coal mining in the 1980s has meant that even thirty years later, former UK coal-mining regions have typically seen rates of unemployment between 3 and 6 percent higher than the national average.

While HM Government (2011), did report the demand for work force that are skillful in green economy needs a skills that is able to support resource efficiency, low carbon industry, durability towards climate and skills that can manages natural assets. All these types of assets are required in all sectors in which some of them are efficient resources oriented, scientist and engineers that apply their knowledge for renewable energy and nuclear energy to reduce pollution, scientific and technical skills to interpret climate change projections for the nature. Thus, a green skill is needed to fill the gap.

Brown (2013) who did a research regarding the four types of cohort perception that is found in the TAFE institute in Australia about the green skills growth. Through this research, most respondents are optimistic about the green skills, however, many risks will be faced. Several jobs will appear and more changes will happen in the work and skills application angle. A clear marketing is getting bigger in renewable energy, saving energy, sustainable water system, green development and recycling. Each job are seen to be considering and instilling sustaining skills.

Thus, by developing a low-carbon economy for green, sustainable growth, governments can have the best of both worlds. They can meet climate change obligations and reduce unemployment. To take advantage of the economic opportunities provided by the low-carbon economy, the workforce needs the right skills, which have to develop the green skills for the green economy.(Cedefop, 2010)

\section{Needs 2: Development of appropriate green technologies}

The critical challenges faced by the micro, small and medium enterprises (MSMEs) in India include adequate and timely availability of credit; development of appropriate technologies for various manufacturing processes which will lead to substantial reduction in cost of manufacturing by enhancing labour productivity, reducing material wastage and minimising energy consumption; appropriate physical infrastructure, marketing and procurement (MMSME, 2013). 
According to WEF $(2018$, ) the developments of the Fourth Industrial Revolution with the most potential for accelerating sustainable production in the automotive, electronics, food and beverage, and textiles, apparel and footwear industries (WEF,2018). Health, safety and emissions regulations are tightening across both developed and developing markets. And, while sustainability is most often linked with the use of the end product, issues such as sustainable sourcing and the circular economy are of increasing importance for the automotive industry (SMMT, 2017). As electric vehicles change the industry's focus from tailpipe emissions to manufacturing, battery life cycles and end-of-life impact, technological advances upstream present opportunities for enhanced resource efficiency, productivity gains and reduced material footprint. Asset light manufacturing, enabled by predictive maintenance, dynamic adjustment of flows and automation, equates to higher machine utilization, reduced capital investment requirements and reduced carbon. Thus, the green skills must be developed to sustainable production in green technologies.

In addition, The European Commission recently adopted an ambitious strategy called Europe 2020 to spur a smart, sustainable and inclusive growth, fostering knowledge, innovation, education and a digital society. The innovation challenge will drive a global systemic transformation, bringing forward new business opportunities and fostering prosperity in a world of finite resources. A new culture of greater resource efficiency and disruptive innovation will require new technologies, processes and materials. Moving towards a circular economy is a framework for future transformation, an opportunity to rethink and redesign the future to address today's fundamental challenges, from how to use natural resources, how to design and manufacture products, through recycling and re-use towards a zero-economy waste and society. Hence, the needs of green skills will be required to develop appropriate technologies to support the new innovation.

\section{Needs 3: Education and skills for green economy, social and environment.}

Lethoko (2014) who studied the relevance between government policy, green economy and education as well as exercise in determining the way the education sector responds towards green economic skills in South America. The experiment discovered that green economy influences skills in three ways which is to bring back green development, developing green technology and to consummate green skills among workers. The industry's needs towards working skills are increasing, however the world is still lacking in that power force. There are several setbacks and issues in instilling green skills. While McCoy, Patrick, O'Brien, Novak and Cavell (2012) in their research stated that green skills issue needs to be solved with the training and education program that exists, as it will help in channeling green skills training to workers in the construction sector effectively. With that, the research has uncovered many challenges towards the training to form a green job that exists in the green industry development as well as ways to overcome it.

The whole world, including Malaysia, has now caught on to providing education that contains green elements, such as green economy, green technology, green education, and green skills and also up skilling the skill for 4IR. Ruzian and Norizan (2014) underline the concept of green technology that is interconnected with Green Skills. Activities involving green energy are seen as a medium to help 
INTERNATIONAL JOURNAL OF ACADEMIC RESEARCH IN BUSINESS AND SOCIAL SCIENCES Vol. 8, No. 9, Sept. 2018, E-ISSN: 2222-6990 @ 2018 HRMARS

human conserve the environmental sustainability, which is realized through green technology industries. Green technology will begin to develop and it will create a new dimension in green skills, which will be in high demand in the future (Ghansyam, 2015: Ramlee, 2015: Arasinah et.al, 2016).

Jagannathan (2013) stated that the training and education system has to emphasize on the level of skills, education and training that is needed for the whole cooperation and greening economy spectrum. High technical and scientific is needed in the context of reducing pollution, creating cities, transportation system and a habitat that produces a low carbon that is pleasant. His research also stated that the most important aspect is to ensure that the training and education system becomes more innovative and foreseeable. While they are preparing necessities for professional green work force, they also play an important role and influence the provision of community that is sustainable and durable. Education is needed to widen the new curriculum training and launch a promotional green business campaign. Technical and vocational training will be more critical in building a foundation that is needed for green jobs. This is similarly to Ramlee (2015) stresses that education and training play an important role in the success of transitioning the economy to the development of green economy and clean environment conducive for the overall economic growth. Thus, elements of sustainability or green skills should be included in the curricula of schools, universities and skills training centers to provide human resources that are conscious of the environment.

Education and Technical and Vocational Training (TVET) is an agent that facilitates the creation of a sustainable workforce towards the Fourth Industry Revolution. There is a need for a workforce equipped with sustainability values in order to overcome the globalisation issues involving climate change and other adverse effects. Pavlova and Huang (2013), researched on the types of values that can be instilled TVET to deliver the green skills agenda. The values that should be instilled in the green skills in care which is to not harm the environment, hold on to science, work hard, unite, be helpful, discipline, obey the law as well as honesty and integrity even thought chaos ensues, understand the modest lifestyle and work hard for it. Thus, the technical and vocational education, through a greater sustainability-related curriculum, plays a crucial role in educating students to be aware of the environment and the integration of green skills in the TVET curriculum is a must. The education and training institutions in Malaysia have to figure out a method that will provide the younger generation with a thorough awareness about the importance of conserving the environment for the welfare of everyone. (Arasinah, Amarumi ,Bushra Limuna, Normah\&Faizal Amin, 2017)

Besides that, Kennedy and Chow (2013) did a research on the role of schools in increasing the understanding regarding the environment as a key community value that has potential to influence not only attitude but a person's actions. Their research also stated that there is an issue in the execution of green skills in schools whether the schools is able to react proactively in supporting students to be tied to the agenda regarding personal and social which is the one related to the future of the community. This research is carried out on Asian citizens who consist of West Asia; Hong Kong, China, Taipei, Republic of Korea and South East Asia; Thailand and Indonesia. The findings of this experiment shows that while environmental education is used as a school curriculum for most students in selected countries, the result is not the same and the chances of students to know about 
the problems with the environment is also not the same according to different areas. Therefore, different areas will require different types of green skills.

In addition, David Consoli (2015) finds that emission reduction entails an increase in demand for scientists and engineers has important policy implications, with education emerging as a critical ingredient in the policy mix to promote sustainable economic growth. An increase in the supply of these skills would pin down the wages of engineers and scientists thus reducing the cost of adopting clean production methods as well as harmful economic consequences of environmental regulation. Hence, green skills are needed into education to support the sustainable of economy, environment and social.

Based on the discussion, there three major needs in green skills development towards 4IR which are:

- Employee productivity - reemployment, green job opportunities, wage, reduce unemployment

- Green technologies - material shortage, automation, smart manufacturing, innovation

- Education - skills for green economy, up-skilling, social skills, environmental skills

\section{Conclusions and Recommendations}

Green skills are essential to ensuring a transition into a low-carbon economy and innovation of Fourth Industrial Revolution. To ensure the productivity of employee, green skills are needed to the current and future industry. This is important to reduce unemployment, increase wage, green job opportunities and reemployment in new business model. Besides that, green skills are needed to develop appropriate technologies so that it will realign to the smart manufacturing, automation, material shortage, and innovation. Education plays the major roles to develop skills for green economy, up skilling 4IR, social skills and environmental skills. Therefore, integrating sustainability education into the TVET curriculum and any training institute, particularly the green skill element, will benefit mankind, environment and economy. Besides that, the policy makers should take the necessary actions such as promoting basic skills, and green skills so that well-equipped workers can meet the challenges of sustainable development towards Fourth Industrial Revolution in their work place. At the same time, coherent policies must be introduced and there should be coordinated implementation of education and training for sustainable development in Fourth Industrial Revolution.

\section{References}

ACET (2015). Asia-Pacific Conference on Education and Training 2015. Retrieved from http://ravte.asia/unesco-asia-pacific-conference-on-education-and-training-acet-2015.

AFD (Agence française de Développement)2017. Green work and professions: review of ILO documentation. Paris, AFD. 
INTERNATIONAL JOURNAL OF ACADEMIC RESEARCH IN BUSINESS AND SOCIAL SCIENCES

Vol. 8, No. 9, Sept. 2018, E-ISSN: 2222-6990 (C) 2018 HRMARS

Afroz, R., \& Rahman, A. (2017). Health Impact of River Water Pollution in Malaysia. International Journal of Advanced and Applied Sciences, 4(5):78-85. Retrived from http://sciencegate.com/IJAAS/V4I5/afroz.html

Arasinah, K., Amarum, A., Bushra, L., Normah,. \& Faizal, A. (2017). Integration of Green Skills in Sustainable Development in Technical And Vocational Education. International Journal of Engineering Research and Applications, pp. 08-12.

Arasinah, K., Ramlee,M., Waliza,. \& Bushra, L. (2016). Green Skills as an Added-Value Element in Producing Competent. International Journal of Engineering Research and Application, pp1221.

Asia Business Council (2009). Addressing Asia's New Green Job Challenge. Retrieved from http://www.asiabusinesscouncil.org/docs/GreenJobs.pdf.

Brown, M. (2013). The Development Of Green Skill Through The Local TAFE Institute As A Potential Pathway To Regional Development. International Journal of Training Research, 11 (1), 27 - 43.

Caldecott, B., Sartor, O. (2018). Implementing coal transitions: Insights from case studies of major coal-consuming economies. IDDRI and Climate Strategies.

Cedefop (2010). Skills supply and demand in Europe: Medium-term forecast up to 2020. Luxemburg: Publication Office of the European Union. Retrieved from www.cedefop.europa.eu/files/3052_en.pdf.

Cedefop (2014). Green skills and jobs. OECD Green Growth Series.

Chinhao. C., Weidou, N., Ma L.W., Pei, L. \& Zheng, L. (2015). The Use of Energy in Malaysia: Tracing Energy Flows from Primary Source to End Use. ISSN 1996-1073. Retrieved from www.mdpi.com/journal/energies

CIVTE. (2014).Systematic Design of Green Skills Development in TVET.Human Resources Development Working Group

Consoli, D., Marin, G., Marzucchi, A. and Vona, F.,(2016). Do green jobs differ from non-green jobs in terms of skills and human capital? Research Policy,45 (5), 1046-1060. doi10.1016/j.respol.2016.02.007

Crishna Morgado, N. and Lasfargues, B. (2017). Engaging the private sector for green growth and climate action: An overview of development co-operation efforts. OECD Development Cooperation Working Papers, No. 34, OECD Publishing.

DEEWR (2011). Department of Education, Employment and Workplace Relation Report. 
INTERNATIONAL JOURNAL OF ACADEMIC RESEARCH IN BUSINESS AND SOCIAL SCIENCES Vol. 8, No. 9, Sept. 2018, E-ISSN: 2222-6990 (C) 2018 HRMARS

EPU THRUST 6, 11TH M P (2015) ELEVENTH MALAYSIA PLAN 2016-2020. Retrieved from Pursuing Green Growth for Sustainability. http://onlineapps.epu.gov.my/rmke11/rmke11 english.html.

Green Skills Agreement Implementation Plan 2010-2011 (2010). Ministerial Council for Tertiary Education and Employment. Retrieved from http://www.ivet.com.au/cgibin/user.pl?download_file=1\&file=18.

HM Goverment. (2011). Skills for green economy. Retrieved from https://www.gov.uk/government/uploads/system/uploads/attachment_data/file/32373/111315-skills-for-a-green-economy.pdf

Ikmal Rashmy (2015). Sustainable Development Issues \& Challenges Associate in Malaysia. Retrieved from https://www.researchgate.net/publication/290602497

ILO (2010). World Social Security Report: Providing Coverage in Times of Crisis and Beyond. Geneva. Retrieved from www.ilo.org/gimi/gess/RessShowRessource.do?ressourceld=15263 $\underline{(16 / 02 / 2015)}$

International Labour Organization. (2014). Global Employment Trends 2014. Geneva: ILO. Jagannathan, S. (2013). Education and skills in Asia: Responding to greening economies. InR.Maclean et al. (eds), Skills Development for Inclusive and Sustainable Growth in Developing Asia-Pacific. New York: Springer.

Kitchenham, B., \& Charters, S. (2007). Guidelines for performing Systematic Literature Reviews in Software Engineering. EBSETechnical Report Version 2.3, EBSE-2007-.

Lethoko, M. (2014). Green economy job projections vs green skills: Is there a link between present skills base and the projected numbers in South Africa?. International Journal Of African Renaissance Studies, 113-132.

McCoy, A. P., Patrick,. O’Brien, P., Novak, V., \& Cavell, M. (2012). Toward understanding roles for education and training in improving green jobs skills development. International Journal of Construction Education And Research, 8 (3), 186-203.

Multilateral environmental agreements subscribed by Malaysia. 2015. Malaysia Biodiversity Information System (MyBIS). Retrieved from https://www.mybis.gov.my/art/19.

MMSME (2013).Micro, Small, and Medium Enterprise (MSME) Report. Retrieved from http://dcmsme.gov.in/ANNUAL REPORT-MSME-2013-14P.pdf

Mokthsim, N. and Salleh, K. O. (2014). Malaysia's Efforts Toward Achieving a Sustainable Development: Issues, Challenges and Prospects. Procedia - Social and Behavioral Sciences.

Munasinghe, M. (2002). The Sustain economics Trans-disciplinary Meta-framework for making Development more Sustainable: applications to energy issues. International Journal of Sustainable Development, Vol. 4, No.2, pp.6-54. 
INTERNATIONAL JOURNAL OF ACADEMIC RESEARCH IN BUSINESS AND SOCIAL SCIENCES

Vol. 8, No. 9, Sept. 2018, E-ISSN: 2222-6990 (C) 2018 HRMARS

Pavlova, M., \& Huang, C. L. (2013). Advancing Employability and Green Skills Development: Values Education in TVET, the Case of the People's Republic of China In Skills development for inclusive and sustainable growth in developing Asia-Pacific Technical and Vocational Education and Training. Issues, Concerns and Prospects, 18, 327-343. Retrieved from http://download.springer.com/static/pdf/487/chp\%253A10.1007\%252F978-94-007-5937

Ramlee (2015). Green and Sustainable Development for TVET in Asia. The International Journal of Technical and Vocational Education.Invotec XI:2

Ruzian, M. \& Norizan, H. (2014). Kelestarian Alam Sekitar dan Pembiayaan Teknologi Hijau dari perspektif Undang-undang Syariah. Retrieved from http://jurnalkanun.dbp.my/wordpress/wp-content/uploads/2014/11/7-Kelestarian-AlamSekitar1.pdf

Schwab, K. The Fourth Industrial Revolution.World Economic Forum, 2017. Retrieved from https://www.weforum.org/about/the-fourth-industrial-revolution-by-klaus-schwab.

SMMT(2017). SMMT MOTOR INDUSTRY FACTS 2017. Retrieved from https://www.smmt.co.uk/wpcontent/uploads/sites/2/ SMMT-Motor-Industry-Facts2017_online_May.pdf

Statistic Department of Malaysia. Population Projection Revise, Malaysia 2010-2040. Retrieved from https://www.dosm.gov.my.

Strietska-Ilina, Olga; Hofmann, C; DuránHaro, M. \& Jeon, S. (2011). Skills for green jobs. A global view: Synthesis report based on 21 country studies. Spain: International Labour Organization. Retrieved from http://www.ilo.org/wcmsp5/groups/public/---dgreports/--dcommpubl/documents/publication/wcms_159585.pdf

Tenaga Nasional Berhad (2010). Green Energy and Technology Issues and Challenges. Asia-Pacific Economic Cooperation. Retrieved from mddb.apec.org/documents/2010/mm/emm/10_emm9_005.pdf

UNESCO. (2012). Education for Sustainable Development: Mission. Retrieved from http://www.unesco.org/new/en/education/themes/leading-the-internationalagenda/education-for-sustainable development/mission/

UNEVOC (2012) International Centre for Technical and Vocational Education and Training. Retrieved from http://www.unevoc.unesco.org/, 2012.

Vona, F., Marin, G., Consoli, D., \& Popp, D. (2015). Green Skills. National Bureau of Economic Research, Working Paper No. 21116. Retrieved from http://www/nber.org/papers/w21116 
INTERNATIONAL JOURNAL OF ACADEMIC RESEARCH IN BUSINESS AND SOCIAL SCIENCES Vol. 8, No. 9, Sept. 2018, E-ISSN: 2222-6990 (C) 2018 HRMARS

World Economic Forum (2018). Driving the Sustainability of Production Systems with Fourth Industrial Revolution Innovation. Retrieved from www.weforum.org/,2018

World Economic Forum (2017). Harnessing the Fourth Industrial Revolution for Sustainable Emerging Cities. Retrieved from https://www.weforum.org

World Bank Malaysia Report (2017).The Inclusive Growth and Development Report 2017.

World Bank (2017), "Enterprise surveys", database, www.enterprisesurveys.org.

World Bank/MPI (2016), Vietnam 2035 : Toward Prosperity, Creativity, Equity, and Democracy, World Bank and Ministry of Planning and Investment of Vietnam, World Bank Publishing, Washington, DC. Yatim, P., Ngan, L. and Lam, H.L. (2017).Financing Green Growth In Malaysia: Enabling Conditions And Challenges, Chemical Engineering Transactions, 61, 1579-1584

\section{ACKNOWLEDGEMENT}

We wish to thanks Universiti Kebangsaan Malaysia under the Program of STEM and Minda with Grant Code - GG-2017-017 for funding this research. 